Discussion Paper No. 03-29

Education and Wage Inequality in Germany -

A Review of the Empirical Literature

Andreas Ammermüller and Andrea Maria Weber

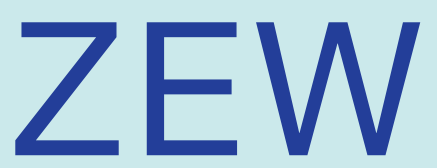

Zentrum für Europäische Wirtschaftsforschung GmbH

Centre for European

Economic Research 
Discussion Paper No. 03-29

\title{
Education and Wage Inequality in Germany - A Review of the Empirical Literature
}

\author{
Andreas Ammermüller and Andrea Maria Weber
}

Download this ZEW Discussion Paper from our ftp server:

\begin{abstract}
ftp://ftp.zew.de/pub/zew-docs/dp/dp0329.pdf
\end{abstract}
Die Discussion Papers dienen einer möglichst schnellen Verbreitung von neueren Forschungsarbeiten des ZEW. Die Beiträge liegen in alleiniger Verantwortung der Autoren und stellen nicht notwendigerweise die Meinung des ZEW dar.

Discussion Papers are intended to make results of ZEW research promptly available to other economists in order to encourage discussion and suggestions for revisions. The authors are solely responsible for the contents which do not necessarily represent the opinion of the ZEW. 


\section{Nontechnical Summary}

This paper reviews the empirical evidence on the link between education and wage inequality in Germany. Due to the positive relationship between education and wages, policy-makers think of education as an efficient instrument to reduce wage inequality, especially by improving the position of the least skilled. However, the possible channels of interaction between the level and spread of education and the wage distribution have hardly been investigated so far.

Summarizing the existing literature leads to the conclusion that there is a relative stability in wage inequality in Germany, both between and within educational levels, as well as in the returns to education. Most changes occurred in East Germany, where the wage distribution widened in the years following reunification, particularly for women.

The inequality in education has decreased, especially through the rise in the educational participation of children from disadvantaged social backgrounds. At the same time, the average educational attainment has risen, with a fall in the percentage of low educated and a rising proportion of highly educated individuals.

Returns to education are found to be slightly decreasing along the conditional wage distribution, which suggests that an increase in the general level of educational attainment should benefit the low wage earners comparatively more. As no drastic changes occurred in the distributions of education and wages over the last decade, however, the relative importance of the effect of the distribution of education upon wage inequality is difficult to identify.

Scope for further research includes an analysis of the link between education and wage inequality for different cohorts and for the most recent data. Moreover, evidence on the direct link between the distribution of wages and the distribution of education is scarce in Germany. In particular, studies relating the distribution and the development of cognitive skills, instead of formal schooling, to wages hardly exist. 


\title{
Education and Wage Inequality in Germany -
}

\author{
A Review of the Empirical Literature
}

\author{
Andreas Ammermüller and Andrea Maria Weber
}

Centre for European Economic Research (ZEW)

L 7,1 D-68161 Mannheim

\begin{abstract}
This paper reviews the current state of knowledge on the link between education and wage inequality in Germany. The wage inequality is characterized by its stability, although a more detailed analysis reveals structural differences, especially between East and West Germany. Both the between and within educational levels wage inequality changed little over time, while there are some tendencies of a converging distribution of education. A need for further research is identified in the effects of education on wage inequality in separate cohorts as well as the direct links between the two distributions in Germany.
\end{abstract}

Acknowledgment: Financial support from the European Commission under the TSER project „Education and Wage Inequality in Europe“ is gratefully acknowledged. We are thankful to Charlotte Lauer for her helpful comments. 


\section{$1 \quad$ Introduction}

This paper reviews some empirical evidence on the link between education and wage inequality in Germany. According to the human capital theory (Becker, 1964), education is an investment in human capital, which yields a return in the form of enhanced future wages. Due to the positive relationship between education and wages, policy-makers think of education as an efficient instrument to reduce wage inequality, especially by improving the position of the least skilled. However, the possible channels of interaction between the level and spread of education and the wage distribution are hardly known.

One major finding of this review is that the German wage inequality is characterized by its stability, although it has increased rapidly in East Germany over the last decade. Concerning education, there has been an educational expansion with an increase in the overall educational participation. There seem to be converging trends in educational attainment with respect to gender and social background. According to the existing literature, returns to education and wage inequality within educational levels have hardly changed. A special feature on the link between education and wage inequality is that there seem to be decreasing returns to education over the wage distribution.

A vast literature examines wage inequality and returns to education and the composition of education is well described, in particular in the sociological literature. However, most studies focus on wage inequality between educational levels. Few studies consider within educational levels wage inequality. Additionally, there is hardly any literature directly linking the distribution of wages and the distribution of education.

In the first part of this paper, we describe the development of wage inequality in Germany during the last twenty years as reported in the literature. Emphasis is given to East-West and gender differences (section 2). Later on, we summarize the German literature on educational inequality. In particular, the question is asked whether there is equal access to and provision of education in the German society (section 3 ). Thereafter, the link between education and wage inequality is explored on the basis of the empirical evidence available for Germany (section 4). Finally, we address the scope for further research (section 5). 


\section{Wage Inequality in Germany}

\subsection{The Data Sources}

One main data source that is used for the analysis of the German wage inequality is the German Socio-Economic Panel (GSOEP). ${ }^{1}$ This is a longitudinal household survey conducted on a yearly basis, in which information on about 12,000 individuals in 6,000 households was collected through interviews starting with the first wave in 1984. As the same persons are interviewed each year, the sample size decreases over time due to dropouts, raising the concern of attrition bias. From 1990 onward, additional data was collected on about 4,500 individuals in 2,200 households in the East of Germany. This figure decreased to 3,700 individuals in 1,900 households in the year 2000. A new sample was drawn in 1998, including 1,900 persons of which 1,500 could be interviewed again in 2000. From there on, an additional sample for the whole of Germany was interviewed, with information on 11,000 persons in over 6,000 households in 2000 .

The data are representative of the composition of the population living in Germany with respect to demographic and socio-economic factors. However, the five largest foreign nationalities living in Germany are deliberately over-sampled in order to give a representative picture of these small-sized population groups. ${ }^{2}$ Therefore, the GSOEP provides weights for each cross-section that account for their probability of being sampled.

Detailed information are available on an individual's work, net and gross monthly earnings, hours of work, educational and demographic background and further characteristics. Most studies that consider wage inequality or analyze the link to education use gross hourly wages. These determine the price of labor for a fixed unit on the labor market and are therefore appropriate for a comparison over time and across countries. Gross monthly earnings are also used in some studies but depend on the hours worked. The impact of taxes and social contributions as in the net wages/earnings is deliberately excluded in order to focus on the price of labor on the labor market and not the labor income of individuals.

Two measures of gross monthly earnings are available in the data. One reports average monthly earnings of the preceding calendar year, the other earnings in the previous month. Most studies use the earnings of the previous month, as this information should be more pre

\footnotetext{
${ }^{1}$ For more detailed information on the GSOEP, see http://www.diw-berlin.de/english/sop .

${ }^{2}$ These include Turks, Spaniards, Italians, Greeks and immigrants from former Yugoslavia.
} 
cise than the persons' assessment of their average earnings over the last year. Together with the hours worked per month, the hourly gross wage can be constructed. ${ }^{3}$

An alternative data set used in the literature is the micro data from the Employment Register (IABS) of the Federal Labor Office, which has become available for scientific use from the late 1990s on. The data provide information on about 200,000 persons in dependent employment living in Germany and being covered by the social security system, which presents a one percent random sample. The gross monthly earnings are reported by the employers to the Labor Office, making the IABS a very accurate source of information.

Despite the smaller sample size of the GSOEP and a less precise reporting of earnings, the GSOEP has distinct advantages compared to the IABS. It is a representative sample of the whole working population, whereas the IABS excludes all civil servants and self-employed persons apart from apprentices. Moreover, it provides detailed information on the hours worked, while the IABS distinguishes only between full and part time. The IABS data do not allow for a distinction between fringe benefits and regular earnings and report the earnings only up to the social security threshold, which implies that about 10 percent of the highest earnings are not fully reported. Therefore, the GSOEP data are preferred to the IABS data in most studies, especially when the distinct parts of the wage distribution are analyzed.

\subsection{Measures of Inequality and Methods}

Various measures to compare wage distributions and to assess the absolute degree of inequality are employed in the studies. The most common ones are the ratio of wage percentiles and income inequality coefficients. While the percentile ratios allow us to compare different parts of the distribution to each other (most common are the 10/50, 10/90, 50/90 percentile ratios), the inequality coefficients give a summary measure of the distribution. The Gini coefficient equals the area between the Lorenz curve and the diagonal divided by the total area under the diagonal of perfect equality (Atkinson, 1995). The Theil indices are alternative measures that have the advantage of complying with the additive decomposability criterion, additionally. An overview of measurements of inequality is presented in the appendix.

Besides the mere description of wage inequality, its structure and development, several studies also try to explain the observed facts. Therefore, they examine the link to education using various methods and decomposition techniques to pin down the effect of education on wage inequality.

\footnotetext{
${ }^{3}$ The number of hours worked is only available for the earnings' measure of the previous month.
} 
Especially for gender wage differences but also for changes over time, decomposition methods are employed that break down the overall wage differences into differences caused by the characteristics of the compared groups, the returns to their characteristics and further terms including the residual effects (Blinder, 1973; Oaxoca, 1973). Therefore, the method allows for a separate consideration of several effects that impact on wage inequality.

\subsection{The Extent of Overall Wage Inequality}

Several studies have described the German wage distribution as relatively compressed and stable over the last 20 years compared to other major economies. This characterization arose from comparisons with the rapidly rising wage inequality in the U.S. in the 1980s (Blau and Kahn, 1996; Freeman and Katz, 1992; Gottschalk and Smeeding, 1997).

Abraham and Houseman (1995) observe decreasing percentile ratios in the lower part of the distribution between 1978 and 1988 using GSOEP and IABS data. A more detailed analysis of the IABS data, which was available to Abraham and Houseman (1995) only in an aggregated way, shows however an increase in percentile differences in the upper part of the distribution for the intermediate education levels (Fitzenberger et al., 2001). The evidence on the German wage inequality is summarized in Table 1, which gives an overview of the data and methods used in the respective studies. Other researchers using the IABS data challenge altogether the view of a relatively stable earnings distribution and describe an increasing spread of earnings for men (Möller, 1996; Möller and Bellmann, 1996). Odink and Smits (2001) also notice a slight increase in the Theil T index, which uses wage shares as weights, for inequality in the wage distribution in the period from 1984 to 1988 but a decrease in the following period up to 1992. They describe the wage distribution as stable over the entire span of their observations from 1984 to 1997 . However, all observed changes over time were quite small and no study mentioned a drastic increase in inequality.

In an attempt to resolve the question on the developments in the earnings distribution in the 1980s, Steiner and Wagner (1998) analyze both IABS and GSOEP data in the years between 1980 and 1990 and come up with somewhat differing results when using the two data sets. While there is no apparent increase in percentile ratios in the GSOEP data, a slight increase in inequality is implied by the IABS data. The authors speak of a relative stability of the earnings distribution in the observed period, though.

For the 1990s, the percentile ratios reflecting the overall wage inequality in West Germany are described as remarkably stable with a slight increase in the mid-90s (Prasad, 2000), although a more differentiated picture is presented in the following structural analysis. 


\subsection{Structure of Wage Inequality}

Major topics in the German literature discussed in relation to wage inequality are the different developments in East and West Germany during the 1990s and gender differentials.

\section{The East-West Wage Gap}

In the 1990s, the developments in wage inequality are more heterogeneous than depicted above, due to the affiliation of East Germany that moved from a socialist toward a market economy and thus to market wages. Under socialism, wages were not determined by the forces of demand and supply on the labor market but were artificially compressed, leading to a much denser wage distribution in East than in West Germany in 1990, although even under socialism substanial wage differentials existed (Franz and Steiner, 2000). Several studies analyze the distinct development of wages in East and West Germany separately for each gender. In West Germany, the increase in percentile ratios describing the wage inequality was small and occurred only among men while the inequality decreased slightly for women (Steiner and Hölzle, 2000). The same could be observed for the distribution of monthly earnings (Riphan, 2002). For East Germany, the studies remark a rapid widening of the formerly compressed wage distribution, especially for women. Between 1990 and 1997, the ratio of the $90^{\text {th }}$ to the $10^{\text {th }}$ percentile increased from 2.02 to 2.48 for men and from 2.18 to 2.97 for women in East Germany, which reflects the faster wage convergence for women toward Western wage levels (Steiner and Hölzle, 2000). By 1999, wage inequality in the East was greater for women than for men and the female wage inequality had already surpassed those of men and women in the West. For men, the inequality was still slightly greater in the West, where the wage inequality for males was higher than for females (Riphan, 2002).

After a rapid convergence of wages in the first years following unification, which benefited mostly the low-wage earners and the less-educated according to Hunt (1999), the process of convergence came to a halt in 1995 and left a still considerable wage gap of about one third of Western wages for men between East and West Germany in 1997. The wage gap between Eastern and Western women is found to be less sizeable, probably due to a selection process in terms of labor market participation of the best female employees in the East (Steiner and Hölzle, 2000).

\section{The Gender Wage Gap}

According to Fitzenberger and Wunderlich (2000), who analyze IABS data by quantile regressions, the gender wage gap decreased especially in the lower part of the wage distribu 
tion in West Germany in the period of 1975-95. In East Germany the gender wage gap is described as decreasing from 17.2 percent in 1990 to an astonishingly low 5.2 percent in 1997 as a result of the more rapidly increasing wages of women (Gang and Yun, 2001). As this seems to be mainly the consequence of a positive self-selection in female labor market participation, the actual gender discrimination did probably not decrease in East Germany and women still face much higher employment difficulties than men (Hunt, 2002). In West Germany, the gender wage gap decreased as well, from about 43 percent in the mid-eighties to 36 percent in the mid-nineties. The reduction is found to be attributable to less discrimination across gender with respect to the returns to education and to the increasing human capital endowment of women (Lauer, 2000).

\begin{tabular}{|c|c|c|c|c|c|}
\hline \multicolumn{6}{|c|}{ Table 1: Evidence on wage/earnings inequality in Germany } \\
\hline Name of Study & Data Sets & Sample & Measure & Method & Major Results \\
\hline $\begin{array}{l}\text { Abraham and } \\
\text { Houseman } \\
(1995)\end{array}$ & $\begin{array}{l}\text { GSOEP, } \\
\text { IABS in } \\
\text { aggregated } \\
\text { form }\end{array}$ & $\begin{array}{l}1978-88 \\
\text { male full-time } \\
\text { workers }\end{array}$ & $\begin{array}{l}\text { Monthly } \\
\text { earnings }\end{array}$ & $\begin{array}{l}\text { Percentile ra- } \\
\text { tios, variance }\end{array}$ & $\begin{array}{l}\text { Stable earnings distribution } \\
\text { 1978-83, decrease in ine- } \\
\text { quality } 1983-88 \text {, especially } \\
\text { lower part }\end{array}$ \\
\hline $\begin{array}{l}\text { Steiner and } \\
\text { Wagner (1998) }\end{array}$ & $\begin{array}{l}\text { GSOEP, } \\
\text { IABS }\end{array}$ & $\begin{array}{l}1980-90 \\
\text { male employees; } \\
\text { Aged } 16-66\end{array}$ & $\begin{array}{l}\text { Monthly } \\
\text { earnings }\end{array}$ & $\begin{array}{l}\text { Percentile ra- } \\
\text { tios }\end{array}$ & $\begin{array}{l}\text { Slight increase for IABS, } \\
\text { none for GSOEP data }\end{array}$ \\
\hline $\begin{array}{l}\text { Odink et al. } \\
(2001)\end{array}$ & GSOEP & $1984-97$ & $\begin{array}{l}\text { Hourly } \\
\text { wages }\end{array}$ & Theil T index & $\begin{array}{l}\text { Slight decrease of wage } \\
\text { inequality } 1984-92 \text {, slight } \\
\text { increase } 1992-97\end{array}$ \\
\hline Hunt (2002) & GSOEP & $\begin{array}{l}1990-94 \\
\text { East Germany; } \\
\text { Aged 18-60 }\end{array}$ & $\begin{array}{l}\text { Monthly } \\
\text { earnings }\end{array}$ & $\begin{array}{l}\text { Blau-Kahn } \\
\text { decomposition }\end{array}$ & $\begin{array}{l}\text { Decrease in gender wage } \\
\text { gap due to positive self- } \\
\text { selection }\end{array}$ \\
\hline $\begin{array}{l}\text { Fitzenberger and } \\
\text { Wunderlich } \\
(2000)\end{array}$ & IABS & $\begin{array}{l}1975-95 \\
\text { West Germany; } \\
\text { Aged } 25-55\end{array}$ & $\begin{array}{l}\text { Monthly } \\
\text { earnings }\end{array}$ & $\begin{array}{l}\text { Quantile re- } \\
\text { gressions }\end{array}$ & $\begin{array}{l}\text { Decrease in gender wage } \\
\text { gap, especially in lower part } \\
\text { of wage distribution for } \\
\text { low- and medium-skilled } \\
\text { females }\end{array}$ \\
\hline Prasad (2000) & GSOEP & $\begin{array}{l}\text { 1984-97 } \\
\text { full-time workers } \\
\text { West Germany; } \\
\text { Aged 17-65 }\end{array}$ & $\begin{array}{l}\text { Hourly } \\
\text { wages }\end{array}$ & $\begin{array}{l}\text { Stand. Dev., } \\
\text { coefficient of } \\
\text { variation }\end{array}$ & $\begin{array}{l}\text { Overall stable, slight de- } \\
\text { crease } 1984-88, \text { slight in- } \\
\text { crease } 1994-97\end{array}$ \\
\hline Lauer (2000) & GSOEP & $\begin{array}{l}\text { 1984-97 } \\
\text { full-time em- } \\
\text { ployees, West } \\
\text { Germany; 20-60 }\end{array}$ & $\begin{array}{l}\text { Hourly } \\
\text { wages }\end{array}$ & $\begin{array}{l}\text { Adjusted } \\
\text { Blinder-Oaxaca } \\
\text { decomposition }\end{array}$ & $\begin{array}{l}\text { Reduced wage gap is attrib- } \\
\text { utable to increased human } \\
\text { capital of women and fewer } \\
\text { differences in returns }\end{array}$ \\
\hline $\begin{array}{l}\text { Steiner and Höl- } \\
\text { zle }(2000)\end{array}$ & GSOEP & $\begin{array}{l}\text { 1990-97 } \\
\text { empl. East/West } \\
\text { Germany; males } \\
\text { aged 19-65, } \\
\text { females 19-60 }\end{array}$ & $\begin{array}{l}\text { Hourly } \\
\text { wages }\end{array}$ & $\begin{array}{l}\text { Percentile ra- } \\
\text { tios }\end{array}$ & $\begin{array}{l}\text { East: high increase for } \\
\text { women, slight for men; } \\
\text { West: slight increase for } \\
\text { men, decrease for women }\end{array}$ \\
\hline $\begin{array}{l}\text { Gang and Yun } \\
(2001)\end{array}$ & GSOEP & $\begin{array}{l}\text { 1990-97 } \\
\text { East and West } \\
\text { Germany; } \\
\text { Aged 20-65 }\end{array}$ & $\begin{array}{l}\text { Hourly } \\
\text { wages }\end{array}$ & $\begin{array}{l}\text { Adjusted } \\
\text { Blinder-Oaxaca } \\
\text { decomposition }\end{array}$ & $\begin{array}{l}\text { Strong decrease in gender } \\
\text { wage gap in East, but in- } \\
\text { creasing discrimination }\end{array}$ \\
\hline Riphan (2002) & GSOEP & $\begin{array}{l}\text { 1984-99 } \\
\text { full-time workers } \\
\text { East and West } \\
\text { Germany; } \\
\text { Aged 18-65 }\end{array}$ & $\begin{array}{l}\text { Monthly } \\
\text { earnings }\end{array}$ & $\begin{array}{l}\text { Percentile ra- } \\
\text { tios }\end{array}$ & $\begin{array}{l}\text { Increase in inequality for } \\
\text { foreigners, men in West and } \\
\text { women in East in the ' } 90 \mathrm{~s}\end{array}$ \\
\hline
\end{tabular}




\section{Further Topics}

In East and West Germany, wage inequality appears to be higher for both men and women in the private sector compared to the public sector. However, while the earnings in the West rose faster in the private sector, they increased more in the public than private sector in the East (Riphan, 2002).

Another topic that has recently been investigated is the wage inequality among foreigners living in West Germany. The 90/10 percentile ratio for foreigners has increased rapidly from 1.8 in 1990 to 2.7 in 1997 and has surpassed the ratio for Germans in the West. Especially the dispersion of the upper part of the wage distribution increased, implying that an increasing number of foreigners gained access to high paid jobs (Riphan, 2002).

\section{Inequality in Education}

Because education is an essential determinant of wages, the distribution of education will affect the distribution of wages. Therefore, before discussing the link between education and wage inequality in section 4 , the focus of this part of the literature review is to answer questions concerning the inequality of education, i.e. whether there is inequality in the provision of and access to education or in educational attainment.

Since the 1960s, a major objective of the German educational policy has been the policy of "educational expansion", i.e. to increase the participation in education, especially of the less educated groups, in order to reduce social inequalities. Several German studies ask the question whether the German educational policy could manage to achieve this aim. In section 3.1 , some features of the educational system in Germany are explained and the question is asked whether such a system is qualified to reduce social inequality. Some studies on educational inequality are described in sections 3.2 - 3.4 with respect to the data and methods used and their major results. One important finding, common to most studies, is that the social background of the family still exerts some significant impact on the children's educational attainment.

\subsection{Background Information: The German Educational System}

Generally, all primary and secondary schools in Germany are public. School quality is not supposed to vary significantly by school type (as e.g. private vs. public schools). Since the 1950 's, school attendance is offered free of tuition for all school types. Tertiary level education is free of charge with some exceptions like (low) administrational fees or "social contri 
butions" (Studentenwerksbeitrag and Sozialbeitrag). Additionally, financial support is granted to students from low income families up from the tenth grade. ${ }^{4}$ All in all, the German educational system aims at providing "equal opportunities of educational choice" (Dustmann, 2001, p. 4).

To describe the features of the education system in more detail, the 16 states (the socalled Länder) are responsible for the educational policy. Thus, regional differences in the education system exist. School attendance is compulsory starting from the age of six. After having completed four years of elementary school, at the age of ten, German pupils generally have to choose one of three major types of secondary schools, where secondary schoolleaving degrees of different levels can be obtained: The three choices are the Hauptschule (where the lowest secondary degree is obtained after five years), the Realschule (where an intermediate secondary degree is obtained after six years) and the Gymnasium (where the highest level secondary degree, the Abitur is obtained after nine years). These schools differ by the abilities requested from the students. ${ }^{5}$ Pre-tests on the children's ability are not common. Teachers at elementary schools only recommend which secondary school to choose. The type of secondary school chosen by the students largely determines the (desired) future educational career, e.g. only the Abitur degree qualifies students to attend universities.

One major objective of the education policy in Germany is to train students for the specific tasks and skills required by the labor market. This is why vocational training plays a central role within the German educational system and in fact most students choose the path of vocational training (e.g. instead of aiming to get a "higher", tertiary level education). ${ }^{6}$ The compulsory duration of full-time school education amounts to nine years. After completion of this general education, students not choosing to pursue further vocational or general full time studies have to attend part-time vocational training schools for at least three additional years.

The educational system in East Germany differs somewhat from that in West Germany. According to Bellow (1999, p. 276-277), in the so-called "new Länder", i.e. the states of the former German Democratic Republic, the duration from first year of primary school to the last year of the higher secondary school (the Gymnasium) is generally shorter than in the West and takes 12 (instead of 13) years. This is one heritage of the GDR. The state of Brandenburg, where the duration amounts to 13 years, is an exception.

\footnotetext{
${ }^{4}$ This is regulated in the law of the "Bundesausbildungsförderungsgesetz (BAFöG)".

${ }^{5}$ See Lauer and Steiner (2001).

${ }^{6}$ According to Lauer (2003a) about 50 percent of Germans aged 25-65 hold an apprenticeship or another vocational degree in 2000.
} 


\subsection{The Data Sources}

The data sets most often used when analyzing educational inequality in Germany correspond to the ones described in section 2.1. Again, the GSOEP is the most popular data set and is used by Blossfeld (1993), Gang and Zimmermann (1999), Dustmann (2001) and the papers by Lauer. Information on education concerns an individual's highest degree of secondary education, vocational training and higher education. Optionally, information on the highest degree obtained in given educational fields can be used in order to derive years of schooling. The GSOEP does not entail information on the subject of study related to an individual's highest degree. Information on social background is available, e.g. the parents' secondary education level and their vocational or academic degree as well as the father's occupational category.

Below (1999) examines the German Mikrozensus 1995 census data and SchimplNeimanns (2000) uses Mikrozensus and Volkszählungs census data providing cross-section information on educational participation between 1950 and 1989 at intervals of ten years. Only native West-Germans are included. In addition, data on educational background given in the "Occupational and Social Regrouping in the Population" supplementary survey to the Mikrozensus (Zusatzerhebung Berufliche und soziale Umschichtung der Bevölkerung) conducted in April 1971 can be used. The Mikrozensus gives information on school attendance including educational degrees. Possible explanatory variables, as the variables used in Schimpl-Neimanns (2000), are gender, age, highest educational and / or occupational degree of the parents and the household head's (father's) occupational status.

Müller and Haun (1994) and Müller (1994) are based on the "General Population Survey in Social Science“ data (Allgemeine Bevölkerungsumfrage der Sozialwissenschaften (ALLBUS)) stemming from seven surveys conducted in West Germany between 1980 and 1991 and covering 19,665 individuals. Information on the father's occupation, parental education and the parents' number of siblings are available.

Bender and Dietrich (2001) use data from a population registration office sample (Einwohnermeldestichprobe) of households in 100 representatively selected counties in West Germany where information from 2,911 computer assisted telephone interviews and personal interviews conducted by the $I A B$ is added. Foreigners or Germans who obtained their educational degree abroad are not included in the sample. Henz and Maas (1995) use data from the life course study (Lebensverlaufstudie) collected by the Max-Planck Institute for Educational Studies in Berlin for the cohorts of 1919-21, 1929-31, 1939-41, 1949-51, 1954-56 and 195961. The life course study is a retrospective survey including detailed information on family 
background and educational career. Approximately 350 interviews have been conducted per cohort and gender. The study is supposed to be representative of the West German population (compare Henz and Maas (1995), p. 611). Information on social origin and regional characteristics (rural vs. urban areas and southern vs. northern states) is available.

\subsection{Measures of Inequality and Methods}

\section{Inequality Indices}

Numerous measures of inequality are available and correspond to the ones summarized in section 2 (e.g. the standard deviation, the variance or the coefficient of variation). In a study on the macro level, Ram (1990) suggests the standard deviation as an appropriate inequality index. The standard deviation equals to zero if the mean education is zero, which makes sense insofar that education is non-negative.

\section{Participation in Education}

One approach to examine educational inequality between social groups is to look at a group's relative participation in education, e.g. at the ratio of a group's participation on the overall size of the group. Below (1999) compares "educational densities" as defined by the proportion of 16 to 19 year olds participating in education. ${ }^{7}$ These ratios are calculated separately for different groups, i.e. groups created by the father's education and parental occupation by gender and region.

\section{Distribution of Degrees}

Further studies refer to the sociological "status-attainment" approach as suggested by Blau and Duncan (1967) by regressing the highest educational level attained (measured in schooling years) on variables describing social origin. ${ }^{8}$ A further method to analyze education inequality commonly used in sociological studies is to compare educational distributions of different social groups (e.g. Blossfeld (1993) and Müller (1994)). Thus the connection of education and for example social origin is analyzed by simple percentage comparisons of the distribution of education for children with a different social background. However, looking at percentage differences, one confounds effects due to changes in the participation in education ("selection effect") and due to changes in the absolute size of a social group ("expansion ef

\footnotetext{
${ }^{7}$ Compare this method as discussed in Peisert (1967).

${ }^{8}$ See Müller and Haun (1994), p. 230 and Mare (1981). This approach is used by Blossfeld (1993).
} 
fect"). ${ }^{9}$ A further problem is a possible omitted variable bias (spurious correlation), e.g. unobserved factors affecting both education and social origin and driving the observed correlation.

\section{Transition Rates}

Some studies use sequential binary choice models to analyze educational inequality. Following Boudon (1974), the attained educational degree is considered to be the result of a sequence of transition probabilities to the next higher educational level. Thus, Müller and Haun (1994), Müller (1994), Blossfeld (1993) and Schimpl-Neimanns (2000) estimate binary logits on the probability whether a transition to the next higher educational level takes place. However, this choice-theoretic modeling of educational participation developed for the U.S. case is based on the fact that (in the U.S.) each time after having completed one educational level, individuals have to decide between two alternatives, i.e. whether they want to attend the next school level or not. This modeling of educational decisions does not really fit the German case. Students in Germany face decisions concerning various options, e.g. which school to choose after primary school is a decision with three major outcomes (high, intermediate or low level secondary school).

Lauer (2002a; 2003b) suggests a multinomial model. From a choice-theoretical point of view, this would imply that available options are considered simultaneously. Dustmann (2001) models the transition from primary to secondary school using an ordered probit-model, where there are three categories corresponding to the secondary school types. Alternatively, in Lauer $(2002 \mathrm{a} ; 2003 \mathrm{~b})$ the educational process is decomposed into two steps (secondary and post-secondary level education), where the choices at both levels may be correlated.

Hierarchical (nested) logit-models have been developed in order to model the choice between more than two options. These can be used to explicitly model the hierarchical structure of decisions which is assumed when using sequential logit-models. ${ }^{10}$ Schimpl-Neimanns (2000) tests whether a more general nested logit-model is preferable to a multinomial logitmodel and concludes that multinomial logits are most qualified to model educational decisions in Germany.

\subsection{Results from Existing Studies on Educational Inequality in Germany}

There exists a variety of sociological articles on education inequality in Germany. However, as mentioned above, these studies mostly confine to examining the distribution of education by simple percentage comparisons, e.g. over time or by cohort. Furthermore, only

\footnotetext{
${ }^{9}$ See Handl $(1984 ; 1985)$ and Köhler (1992), p. 20-22.
} 
few explanatory variables are considered, for example by looking at educational attainment by the occupational status of the father or the family's sociological class (as created by the parents' occupational status or income etc.). Some of the more important sociological studies and economic studies and their major results are summarized below according to the major aspect of educational inequality they are related to. All the studies refer to West Germany only, with the exceptions of Below (1999) and Ram (1990). The data sets, methods and major results are summarized in Table 2.

\section{Inequality in Education and Social (parental) Background}

According to Lauer (2002a; 2003b) parental education and the father's occupation have a significant impact on educational attainment, where blue collar workers' children are the most "disadvantaged" group and managers' children have the highest outcome. Estimating successive educational stages yields that parental education is also important for post-school educational attainment though to a lesser extent. Similarly, Lauer (2002b) examines the probability to be enrolled in higher education and finds that social origin (in particular parental education and occupational position) is an important determinant. Furthermore, the probability of being enrolled depends on labor market return expectations, especially on the level of personal unemployment risk. A higher probability to be non-employed or employed part-time yields a lower probability to be enrolled in higher education. Expected returns to education (i.e. wages) have a significant impact on the educational decisions. Public policy is found to have an influence on enrolments. Extending public financial support (the $B A F \ddot{o} G$ ) increases enrolments. The proportion of the repayable part of the $B A F \ddot{o} G$ has some impact on enrolments.

Looking at individuals born between 1920 and 1966, Dustmann (2001) shows that there is a strong link between the parents' educational and occupational status and the children's secondary school choice. The probability that a person completes the highest level secondary school is highest for males, whose father holds an intermediate or high level secondary school degree. The same effect is weaker (but positive) for the probability that a male person completes the intermediate secondary school. Interestingly, for females the reverse is true: An intermediate or high level secondary school level of the father exerts the strongest (positive) impact on the probability that the daughter completes the intermediate degree. In the same way, the fact that the father holds a higher level post school degree seems to influ

\footnotetext{
${ }^{10}$ Compare Maier and Weiss (1990) for a theoretical discussion.
} 
ence the children's decision for a higher secondary school. Also, the father's occupational class has a significant effect on the secondary school decision.

Schimpl-Neimanns (2000) finds that social inequality in educational participation decreases over time: In 1989, social origin still exerted some impact on educational attainment; however, the relationship between social background and education experienced significant changes since 1950. The main part of the reduction in inequality occurred before the end of the 1970s. Looking at the choice among secondary schools, Schimpl-Neimanns (2000) concludes that the (significant) influence of the father's occupational status decreased over time. The reduction of inequality related to the parents' education is weaker and occurred later. All in all, Schimpl-Neimanns (2000) even concludes that the significant influence of the parents' education on the relative chances to attend the highest level secondary school compared to the intermediate level secondary school did not decrease in time. This corresponds to findings by Blossfeld (1993), Henz and Maas (1995) and Müller (1994).

Henz and Maas (1995) show that the father's occupation, the parents' education and the number of siblings determine the educational decision significantly. Again, as a rule of thumb, one can say that the better the father's (family's) occupational (educational) position, the higher will be the child's educational outcome. The number of siblings generally exerts a negative impact on the educational outcome. Furthermore, in their descriptive analyses, Müller and Haun (1994) and Müller (1994) show the general trend of educational expansion, where both papers find that the social class of the family seems to have a stronger influence on earlier transitions than on transitions occurring later in the educational career.

As Lauer (2002b; 2003b) and Gang and Zimmermann (1999) show, the impact of the father's education is stronger than the impact of the mother's education. Comparing educational attainment of second generation immigrants and natives in the same age cohort they find that the size of the ethnic network positively influences educational attainment. There is a significant impact of the country of origin on educational attainment in the second generation. The parents' education influences German children's educational choice, while there is no significant impact for the children of foreigners.

Estimating linear regressions on educational levels, Blossfeld (1993) observes a persisting influence of parental background. Again, looking at the secondary educational level, there seems to be a decrease in the impact of social background characteristics. Additionally, the logit estimation on educational transitions indicate that the influence of social background is more important at earlier educational transitions compared to later transitions. 


\section{Gender Differentials}

Lauer (2003a) describes that there are significant gender differences in the distribution of secondary education in Germany. Generally, their has been a significant educational expansion among West German women. 67 percent of West German men hold a Hauptschule degree only in the 1929-38 cohort and 70 percent of the West German women belong to this category. In the 1959-68 cohort, 38 percent of the men hold Hauptschule degrees only and the women (30 percent in the Hauptschule category) have caught up dramatically among the intermediate level degree holders. In the "younger" cohort, the proportion of women belonging to the intermediate level category is significantly larger than the proportion of men (45 percent vs. 35 percent) even if in the "older cohort" the proportions are about the same (22 percent vs. 21 percent). Furthermore, the presence of women in the high level secondary education group increased noticeably: 8 percent of the older cohort (compared to 11 percent for males) and 23 percent of the younger cohort (compared to 22 percent for males) hold these degrees. Looking at final educational attainment, Lauer (2003a) finds that much more women than men have no vocational degree in West Germany in 2000 (19 percent compared to 12 percent). However the gender gap decreased over time. Furthermore, the proportion of men holding a tertiary level degree is much higher than the share of women. As concerns basic vocational and intermediate qualification, there seems to be some convergence of the proportions of men and women as well.

According to Lauer (2002a; 2003b) estimating the ordered probits yields higher thresholds for women, i.e. given the family background and cohort, females seem to expect lower returns or higher costs related to education so that their investments in education are lower than those of males. Estimating successive educational stages a strong educational expansion is found, in particular at the secondary school level, which has been stronger for women compared to men.

In a descriptive analysis Bender and Dietrich (2001) examine the difference in educational attainment among gender for the birth cohorts of 1964 and 1971 respectively. They find that the educational distribution has changed in favor of females. According to this paper, women generally obtained higher educational degrees compared to men in the 1964 cohort. 28.4 percent (38.4 percent) of all women (men) were in the Hauptschule category while most women held a Realschule degree (40.6 percent compared to 31,3 percent for males) and fewer women held an Abitur degree (27.6 percent vs. 25,7 percent for males). In 1971 the proportions have changed in favor of the Abitur group: 20.2 percent (30.9 percent) of the interviewed women (men) remain in the Hauptschule degree group while 38.2 percent (33.1 per 
cent) obtain a Realschule degree and 39.4 percent (33.8 percent) the Abitur. Similarly, Müller and Haun (1994), Müller (1994) and Blossfeld (1993) find that the gender gap in educational attainment decreases.

\section{Development over Cohorts}

Comparing the distribution of educational degrees by cohorts gives some idea concerning the future trend of educational attainment. Lauer (2003a) compares an "old" (born between 1929 and 1938) and a "young" birth cohort (born between 1959 and 1968) of West Germans active in the labor market. Looking at secondary education, the proportion of students leaving school without a secondary degree decreases slightly (3 percent and 1 percent respectively). There is a clear decrease of the proportion of individuals having a Hauptschule degree only (68 percent and 34 percent respectively). While only 21 percent ( 9 percent) obtained an intermediate (high) level degree in the cohort of 1929-38, in the cohort of 1959-68 already 40 percent (23 percent) obtain these degrees. As concerns final educational attainment, Lauer (2003a) shows that there is a remarkable decrease in the proportion of persons holding no vocational degree. While 27 percent of the individuals in the cohort of 1929-38 did not hold such a degree, only 10 percent of the 1959-68 cohort belong to this category. Looking at the shares of individuals holding a basic vocational degree, one can see that there is a tendency that relatively fewer persons hold a lower secondary school degree and a basic vocational degree (39 percent in the old and 25 percent in the young cohort) while the proportion of persons having an intermediate secondary school degree and a basic vocational degree increases (11 percent in the old and 21 percent in the young cohort). Furthermore, across cohorts there is an obvious increase in the proportion of persons belonging to the intermediate qualification category (12 percent in the older cohort and 25 percent in the younger cohort) and to the tertiary level degree group (10 percent in the older cohort and 20 percent in the younger cohort). Within the latter group, the increase of persons holding a university degree has been significantly higher compared to the rise of the (lower tertiary) Fachhochschule degrees. All in all, there is a clear trend of an expansion of higher educational degrees.

Looking at the effects of the cohort variables, Dustmann (2001) finds tendencies of convergence over cohorts (and thus over time): The impacts of parental background on children's secondary school choice decreases, where the convergence is stronger for females than for males. One consequence is that the gender differential in high level secondary school attendance seems to disappear for the youngest cohort. Müller and Haun (1994) and Müller (1994) find that examinations of educational attainment by cohort reflect the general expan 
sion in educational participation. Additionally, the influence of social origin seems to be of smaller importance for the younger cohorts than for the older cohorts and this effect is stronger for women than for men. According to Henz and Maas (1995), the cohort effects show the trend to increasing general educational degrees. Concerning the transition to secondary school, social background becomes less important for younger cohorts. For females, social background variables also lose their importance on the vocational degree.

\section{Regional Differences and East Germany}

Below (1999) reports that the overall educational density increased significantly over time. According to this analysis, the educational density is higher for females than for males, especially in the East German states (the so-called "new Länder" states) in 1995. However, children of blue-collar workers, low-qualified or low-educated parents are still underrepresented in higher education. This disadvantage most notably affects males, particularly in states known for a "conservative" educational policy (Bavaria and Mecklenburg-Western Pomerania). At the same time, children of non blue-collar worker families or whose parents are better educated seem not to be influenced significantly by the state's educational policy. In Western Germany, the children of public servants have the highest educational density. Their educational density ranges from 63 percent (Schleswig-Holstein) to 87 percent (Hamburg), while blue-collar workers rank from 33 percent (Bavaria) to 66 percent (Bremen). The children of self-employed and white-collar workers experience a higher educational density than blue-collar workers' children but a lower density compared to public servants. All in all, Below (1999) concludes that significant inequalities regarding to social and regional background still exist even if one observes some tendencies of adjustment.

Concerning regional effects, Henz and Maas (1995) find significant differences among rural and urban areas, as well as between northern and southern states (in favor of the south). Regional differences decrease over cohorts and for the youngest cohort the difference in the educational decision is insignificant. Looking at vocational education of females, the ratio between urban and rural areas even turns around in favor of the rural areas.

\section{A Macro level Study: Educational Expansion and Education Inequality}

Ram (1990) is an example of an international study on a macro level. This study focuses on testing the hypothesis that a general rise in education yields a fall in educational inequality. It is shown that it is not clear whether educational inequality decreases or increases as the average level of education rises. The relationship seems to be rather curvilinear. For West 
Germany the mean education was equal to 8.70 years of education in the eighties (with a standard deviation of 3.23). In East Germany the mean is given by 12.26 (and the standard deviation is 1.91).

\begin{tabular}{|c|c|c|c|c|c|}
\hline $\begin{array}{l}\text { Name of } \\
\text { Study }\end{array}$ & Data Set(s) & Sample & $\begin{array}{l}\text { Additional } \\
\text { Comments }\end{array}$ & Method & Major Results \\
\hline $\begin{array}{l}\text { Lauer } \\
(2003 a)\end{array}$ & $\begin{array}{l}\text { German Socio- } \\
\text { Economic Panel } \\
\text { (GSOEP) }\end{array}$ & $\begin{array}{l}\text { West Germans } \\
\text { active in the } \\
\text { labor market and } \\
\text { aged } 25-65 \text {. }\end{array}$ & $\begin{array}{l}\text { Final educational } \\
\text { attainment as a com- } \\
\text { bination of secondary, } \\
\text { vocational and higher } \\
\text { education. }\end{array}$ & $\begin{array}{l}\text { Distributions of } \\
\text { (secondary/ } \\
\text { final) attainment } \\
\text { (over time, by } \\
\text { cohort, gender). }\end{array}$ & $\begin{array}{l}\text { Educational } \\
\text { expansion. } \\
\text { Gender differ- } \\
\text { ences, especially } \\
\text { by cohorts. }\end{array}$ \\
\hline $\begin{array}{l}\text { Lauer } \\
(2002 a) \\
\text { and } \\
\text { Lauer } \\
(2003 b)\end{array}$ & $\begin{array}{l}\text { German Socio- } \\
\text { Economic Panel } \\
\text { (GSOEP). }\end{array}$ & $\begin{array}{l}\text { West Germans } \\
\text { born between } \\
1929 \text { and } 1968 \\
\text { only (waves } \\
1985-1999) .\end{array}$ & $\begin{array}{l}\text { Educational outcome } \\
\text { defined as the highest } \\
\text { obtained degree based } \\
\text { on } 5 \text { levels. Explana- } \\
\text { tory variables: Cohort } \\
\text { dummies, the father's } \\
\text { occupation, parental } \\
\text { education, gender. }\end{array}$ & $\begin{array}{l}\text { (1) Ordered } \\
\text { probit-model. (2) } \\
\text { Decomposition } \\
\text { into school and } \\
\text { post-school } \\
\text { education (mul- } \\
\text { tivariate ordered } \\
\text { probit). }\end{array}$ & $\begin{array}{l}\text { Parental charac- } \\
\text { teristics influ- } \\
\text { ence educational } \\
\text { attainment. Pa- } \\
\text { rental education } \\
\text { is also important } \\
\text { for post-school } \\
\text { attainment. }\end{array}$ \\
\hline $\begin{array}{l}\text { Bender } \\
\text { and } \\
\text { Dietrich } \\
(2001)\end{array}$ & $\begin{array}{l}\text { Data from a popu- } \\
\text { lation registration } \\
\text { office sample } \\
\text { (Einwohnermeld- } \\
\text { estichprobe) of the } \\
\text { IAB in } 100 \text { selected } \\
\text { counties are used. }\end{array}$ & $\begin{array}{l}\text { Cohorts of } 1964 \text { / } \\
1971 \text { (West } \\
\text { Germans). Per- } \\
\text { sons having } \\
\text { obtained their } \\
\text { educational de- } \\
\text { gree abroad are } \\
\text { excluded. }\end{array}$ & $\begin{array}{l}\text { The analysis refers to } \\
\text { considerations by } \\
\text { cohort and by gender. }\end{array}$ & $\begin{array}{l}\text { Descriptive } \\
\text { analysis, propor- } \\
\text { tions of indi- } \\
\text { viduals having } \\
\text { obtained some } \\
\text { educational } \\
\text { degree. }\end{array}$ & $\begin{array}{l}\text { Educational } \\
\text { distribution } \\
\text { changed in favor } \\
\text { of females. } \\
\text { Women gener- } \\
\text { ally obtain } \\
\text { higher secondary } \\
\text { degrees. }\end{array}$ \\
\hline $\begin{array}{l}\text { Lauer } \\
(2002 b)\end{array}$ & $\begin{array}{l}\text { German Socio- } \\
\text { Economic Panel } \\
\text { (GSOEP), regional } \\
\text { data from the Fed- } \\
\text { eral Office of Sta- } \\
\text { tistics (Statistische } \\
\text { Jahrbücher, Fach- } \\
\text { serien } 11 \& 14 \text { ) } \\
\text { and from the Fed- } \\
\text { eral Ministry of } \\
\text { Research and Edu- } \\
\text { cation (Grund- und } \\
\text { Strukturdaten). } \\
\end{array}$ & $\begin{array}{l}\text { West Germans in } \\
1984-1997 \text { aged } \\
21-26 \text { are con- } \\
\text { sidered. }\end{array}$ & $\begin{array}{l}\text { The dependent vari- } \\
\text { able indicates univer- } \\
\text { sity attendance. Re- } \\
\text { gressors: household } \\
\text { income, the father's } \\
\text { economic situation / } \\
\text { occupation, local } \\
\text { labor market charac- } \\
\text { teristics, education } \\
\text { policy (public expen- } \\
\text { ditures, student- } \\
\text { teacher ratio), age, } \\
\text { gender, nationality. }\end{array}$ & $\begin{array}{l}\text { Ordered probit- } \\
\text { model on the } \\
\text { probability of } \\
\text { being enrolled in } \\
\text { higher education. }\end{array}$ & $\begin{array}{l}\text { Parental educa- } \\
\text { tion and occupa- } \\
\text { tion, the cover- } \\
\text { age of public } \\
\text { financial support } \\
\text { and labor market } \\
\text { expectations are } \\
\text { important for the } \\
\text { children's edu- } \\
\text { cational deci- } \\
\text { sion. }\end{array}$ \\
\hline $\begin{array}{l}\text { Schimpl- } \\
\text { Nei- } \\
\text { manns } \\
(2000)\end{array}$ & $\begin{array}{l}\text { Mikrozensus and } \\
\text { Volkszählungs- } \\
\text { census data and a } \\
\text { supplementary } \\
\text { survey to the } \\
\text { Mikrozensus. }\end{array}$ & $\begin{array}{l}\text { West Germans } \\
\text { only, data on } \\
1950-1989 \text { at } \\
\text { intervals of ten } \\
\text { years. }\end{array}$ & $\begin{array}{l}\text { Information on school } \\
\text { attendance/ attained } \\
\text { educational degree is } \\
\text { used. Explanatory } \\
\text { variables: gender, age, } \\
\text { parental education / } \\
\text { occupation. }\end{array}$ & $\begin{array}{l}\text { It is tested } \\
\text { whether a more } \\
\text { general nested } \\
\text { logit is prefer- } \\
\text { able to a multi- } \\
\text { nomial logit- } \\
\text { model. }\end{array}$ & $\begin{array}{l}\text { Multinomial } \\
\text { logits most } \\
\text { qualified to } \\
\text { model education. } \\
\text { Social inequality } \\
\text { decreases over } \\
\text { time. }\end{array}$ \\
\hline $\begin{array}{l}\text { Below } \\
(1999)\end{array}$ & $\begin{array}{l}\text { Mikrozensus cen- } \\
\text { sus data. }\end{array}$ & $\begin{array}{l}\text { The sample re- } \\
\text { fers to } 1995 .\end{array}$ & $\begin{array}{l}\text { Ratios are calculated } \\
\text { by groups created by } \\
\text { the father's education, } \\
\text { parental education, } \\
\text { gender and region. }\end{array}$ & $\begin{array}{l}\text { Educational } \\
\text { densities (pro- } \\
\text { portions of 16-19 } \\
\text { year olds partici- } \\
\text { pating in educa- } \\
\text { tion); odds ra- } \\
\text { tios. }\end{array}$ & $\begin{array}{l}\text { Educational } \\
\text { density higher } \\
\text { for females, } \\
\text { especially in } \\
\text { East Germany. } \\
\text { Inequalities by } \\
\text { social/ regional } \\
\text { background. }\end{array}$ \\
\hline $\begin{array}{l}\text { Dust- } \\
\text { mann }\end{array}$ & $\begin{array}{l}\text { German Socio- } \\
\text { Economic Panel }\end{array}$ & $\begin{array}{l}\text { West Germans } \\
\text { only. Data refer }\end{array}$ & $\begin{array}{l}\text { Explanatory variables: } \\
\text { Parents' secondary }\end{array}$ & $\begin{array}{l}\text { Transition from } \\
\text { primary to sec }\end{array}$ & $\begin{array}{l}\text { Strong (but de- } \\
\text { creasing) link }\end{array}$ \\
\hline
\end{tabular}




\begin{tabular}{|c|c|c|c|c|c|}
\hline (2001) & (GSOEP). & $\begin{array}{l}\text { to } 1984-1987, \\
\text { individuals aged } \\
21-66 .\end{array}$ & $\begin{array}{l}\text { education, vocational } \\
\text { or academic degree, } \\
\text { father's occupation, } \\
\text { cohort and gender. }\end{array}$ & $\begin{array}{l}\text { ondary school } \\
\text { (ordered probit- } \\
\text { model, } 3 \text { secon- } \\
\text { dary levels). }\end{array}$ & $\begin{array}{l}\text { between parental } \\
\text { background and } \\
\text { the children's } \\
\text { education. }\end{array}$ \\
\hline $\begin{array}{l}\text { Gang and } \\
\text { Zim- } \\
\text { mermann } \\
(1999)\end{array}$ & $\begin{array}{l}\text { German Socio- } \\
\text { Economic Panel } \\
\text { (GSOEP). }\end{array}$ & $\begin{array}{l}\text { West Germany, } \\
\text { wave } 1984 \text {. For- } \\
\text { eigners born in } \\
\text { Germany/ having } \\
\text { arrived before } \\
\text { the age of } 16,17- \\
38 \text { years old. } \\
\text { Same age cohort } \\
\text { from the German } \\
\text { sample. }\end{array}$ & $\begin{array}{l}\text { Alternative dependent } \\
\text { variables (years of } \\
\text { education, level of } \\
\text { schooling, binary } \\
\text { variable for vocational } \\
\text { training). Explanatory } \\
\text { variables: Size of the } \\
\text { ethnic network, coun- } \\
\text { try of origin, parental } \\
\text { education. }\end{array}$ & $\begin{array}{l}\text { According to the } \\
\text { three types of } \\
\text { dependent vari- } \\
\text { ables, three } \\
\text { models (OLS, } \\
\text { probit and a } \\
\text { binomial probit) } \\
\text { are used. }\end{array}$ & $\begin{array}{l}\text { Impact of the } \\
\text { father's educa- } \\
\text { tion stronger } \\
\text { than impact of } \\
\text { the mother's } \\
\text { education. Size } \\
\text { of ethnic net- } \\
\text { work, country of } \\
\text { origin influence } \\
\text { education. }\end{array}$ \\
\hline $\begin{array}{l}\text { Henz and } \\
\text { Maas } \\
(1995)\end{array}$ & $\begin{array}{l}\text { Data from the life } \\
\text { course study (Le- } \\
\text { bensverlaufstudie) } \\
\text { collected by the } \\
\text { Max-Planck Insti- } \\
\text { tute for Educa- } \\
\text { tional Studies in } \\
\text { Berlin. }\end{array}$ & $\begin{array}{l}\text { The data refer to } \\
\text { the cohorts of } \\
1919-21,1929- \\
31,1939-41 \text {, } \\
1954-56 \text { and } \\
\text { 1959-61. West } \\
\text { Germans only. }\end{array}$ & $\begin{array}{l}\text { Explanatory variables: } \\
\text { Social origin (father's } \\
\text { occupation, parental } \\
\text { education, number of } \\
\text { siblings), regional } \\
\text { characteristics (rural } \\
\text { vs. urban areas, south- } \\
\text { ern vs. northern } \\
\text { states), cohort. }\end{array}$ & $\begin{array}{l}\text { Logits separate } \\
\text { by gender (tran- } \\
\text { sition from pri- } \\
\text { mary to secon- } \\
\text { dary school, } \\
\text { completion of } \\
\text { secondary } \\
\text { school, comple- } \\
\text { tion of a voca- } \\
\text { tional degree). }\end{array}$ & $\begin{array}{l}\text { The father's } \\
\text { education, pa- } \\
\text { rental education, } \\
\text { regional differ- } \\
\text { ences and the } \\
\text { number of sib- } \\
\text { lings are impor- } \\
\text { tant for the edu- } \\
\text { cational out- } \\
\text { come. }\end{array}$ \\
\hline $\begin{array}{l}\text { Müller } \\
\text { and Haun } \\
(1994) \\
\text { and } \\
\text { Müller } \\
(1994)\end{array}$ & $\begin{array}{l}\text { General Population } \\
\text { Survey in Social } \\
\text { Science (ALL- } \\
\text { BUS), GSOEP and } \\
\text { Mikrozensus cen- } \\
\text { sus data). }\end{array}$ & $\begin{array}{l}\text { West German } \\
\text { data collected in } \\
\text { 1980-92. Census } \\
\text { data: cohorts } \\
\text { 1920-1950. } \\
\text { GSOEP: waves } \\
\text { 1984-86. }\end{array}$ & $\begin{array}{l}\text { Six educational cate- } \\
\text { gories. Explanatory } \\
\text { variables: Social class } \\
\text { of the family (created } \\
\text { by the father's occu- } \\
\text { pation and education), } \\
\text { gender. }\end{array}$ & $\begin{array}{l}\text { Descriptive } \\
\text { statistics and } \\
\text { binary logits } \\
\text { whether transi- } \\
\text { tion to the next } \\
\text { higher educa- } \\
\text { tional level takes } \\
\text { place. }\end{array}$ & $\begin{array}{l}\text { Social class has a } \\
\text { stronger influ- } \\
\text { ence on earlier } \\
\text { transitions. Gen- } \\
\text { der gap reduces. } \\
\text { Social origin less } \\
\text { important for } \\
\text { younger cohorts. }\end{array}$ \\
\hline $\begin{array}{l}\text { Blossfeld } \\
(1993)\end{array}$ & $\begin{array}{l}\text { German Socio- } \\
\text { Economic Panel } \\
\text { (GSOEP). }\end{array}$ & $\begin{array}{l}\text { West Germans } \\
\text { included in the } \\
\text { waves 1984- } \\
1988 .\end{array}$ & $\begin{array}{l}\text { Dependent variables: } \\
\text { Educational level ( } 7 \\
\text { levels), } 4 \text { educational } \\
\text { transitions. Independ- } \\
\text { ent variables: The } \\
\text { father's schooling and } \\
\text { occupation, cohort } \\
\text { dummies and gender. }\end{array}$ & $\begin{array}{l}\text { Educational } \\
\text { distributions, } \\
\text { OLS regression } \\
\text { on educational } \\
\text { level and logit- } \\
\text { models for 4 } \\
\text { transitions. }\end{array}$ & $\begin{array}{l}\text { Persisting influ- } \\
\text { ence of parental } \\
\text { variables (de- } \\
\text { creasing at the } \\
\text { secondary edu- } \\
\text { cational level). } \\
\text { Converging } \\
\text { gender effects. }\end{array}$ \\
\hline
\end{tabular}

\section{The Link between Education and Wage Inequality}

As described in the introduction, education as an investment in human capital is an important determinant of wages and their distribution. The link between education and wages has been studied intensively. However, the evidence on the effect of education on wage inequality remains ambiguous. After reviewing the literature on wage inequality and educational inequality, this section intends to establish their link, especially to shed light on the question how education affects the inequality of wages. 
According to Pereira and Martins (2000), education has an impact on the distribution of wages in three ways, at which we will look separately. First of all (1), the price of skills acquired by education and reflected in the returns to education have an impact on the spread of wages. These inter-educational-levels wage differentials have been extensively analyzed over a long time period and will only be recapitulated shortly. Furthermore (2), wage dispersion also exists within educational groups. Only few studies consider this aspect but these are rather recent and constitute the focus of this review. Finally (3), the distribution of education within society changes, which affects the wage distribution through the returns to education. The studies to which the article refers are summarized in Table 3.

\subsection{Wage Inequality between the Educational Levels}

The positive relationship between education and earnings is well established in the empirical literature. Skill prices defining the wage differentials between workers with different levels of education are thereby determined by the supply of and demand for skills on the labor market. Private returns to education relate the investment in an additional year of education to the higher resulting wages.

\section{Methods}

The part of wage inequality between individuals due to a difference in the level of education can be analyzed in terms of the returns to education. In the basic Mincer equation (Mincer, 1974), which is the most prominent wage equation and derived from the human capital theory (Becker, 1964), log hourly wages are regressed on the years of schooling, labor market experience, experience squared and other individual-characteristic variables. The parameter of the schooling variable from the OLS regression represents the marginal returns to an additional year of schooling. The higher the returns to education are, the higher is the wage inequality for a given distribution of education because the effect of differences in the level of education on wages intensifies.

\section{Results}

The private returns to education in Europe have been the subject of the EU project 'Public Funding and Private Returns to Education' (PURE). In a contribution on the evidence available for West Germany, Lauer and Steiner (2001) show that the returns to a year of schooling in the standard Mincer equation are about 8 percent for men and 10percent for women. For the period of 1984 to 1997, these figures stay remarkably stable. In an estimated 
earnings function the skill premium of university graduates even decreases slightly relative to the unskilled between 1984 and 1990 (Steiner and Wagner, 1998). From 1984 to 1997 no apparent increase in the education premia is visible in another wage function (Prasad, 2000). The stability of the returns to education between employees with a different amount of schooling years or formal education is taken as a partial explanation for the observed stability of the wage inequality in Germany during the last two decades.

For East Germany, a wage regression performed by Steiner and Hölzle (2000) shows a declining wage differential between university graduates and unskilled workers in the period of 1990 to 1997 . Therefore, the observed rise in wage inequality is not due to a greater differential between the wages of differently educated workers. A decomposition of the inequality of male wages in East Germany between 1990 and 2000 shows, however, that the returns to education are a major explanatory factor of the increasing wage inequality, together with the firm size premium (Gang and Yun, 2002).

The lasting good position of the low-skilled workers in Germany, at least concerning relative wages, is often explained by their flexible skill formation. The apprenticeship that most low-skilled workers pass through consists of vocational training in firms and formal schooling supplied by the state. This structure may allow for a fast adaptation of the apprenticeship to shifts in the demands for skills, leaving the low-skilled workers in Germany less vulnerable to these shifts (Abraham and Houseman, 1995).

\subsection{Wage Inequality within the Educational Levels}

Empirical evidence shows that wages not only differ between workers with different levels of education but also within narrowly defined educational groups. This within educational levels wage inequality may be due to unobserved skills or other characteristics of workers. In order to understand the link between education and wage inequality and to assess possible effects of changes in the distribution of education, it is important to observe how the variation of wages due to education changes along the conditional wage distribution. This allows us to assess more completely the effect of education as an instrument to reduce wage inequality.

\section{Methods}

The OLS estimates only provide information on the returns to education at the mean of the conditional wage distribution. However, the returns to education may be quite unequal along the entire conditional wage distribution. This is the case if wages are not distributed 
identically around a known function of schooling. Therefore, quantile regressions that can be solved by linear programming methods are employed to estimate the returns to education and other determinants of wages at specific quantiles of the conditional distribution of the dependent variable wages (Bushinsky, 1994). As the educational groups are unequally represented in the different parts of the wage distribution, with many low-skilled workers in the lower part and high-skilled in the upper part, the returns to education at the different percentiles of the wage distribution give inference on the within-educational levels wage inequality.

\section{Results}

Two recent studies analyze the wage inequality within educational levels in Germany by applying quantile regressions to GSOEP data. Pereira and Martins (2000) consider the time span from 1984 to 1995 but base their analysis on only four data points (years of observation). Their quantile regressions estimate the standard Mincer equation, with log hourly gross wages as the dependent variable and the number of schooling years, labor market experience and experience squared as the independent variables.

The second study (Prasad, 2000) has distinct advantages because it considers every year between 1984 and 1997 and uses dummies for the educational achievement instead of schooling years, which facilitates the separate consideration of the quantile regressions for the educational groups. Log hourly gross wages are regressed on three educational dummies, labor market experience, experienced squared, tenure in a firm, a dummy for German citizenship and interaction variables between the dummy and all other explanatory variables.

The results of both studies are comparable. According to Pereira and Martins (2000), the returns to education for the full sample of employees decrease when we move up the wage distribution. Employees at the tenth percentile of the wage distribution have higher marginal returns to education than employees at the $90^{\text {th }}$ percentile. The analysis of Prasad (2000) that includes dummies for three educational groups allows for a more differentiated view. For the highest educational group of university graduates, the relationship between the wage distribution and the returns to education is positive, contrary to the results of Pereira and Martins (2000). However, for the two other educational groups, employees with vocational training and with an apprenticeship, the relationship is again negative. As these two groups constitute the majority of employees, the results of the two studies are not necessarily opposing each other. The differences between the lower and upper quantiles are quite small though and appear to fall slightly over time. 
Two further studies apply quantile regressions to German wage data that reach up to the year 1990 (Fitzenberger, 1999; Fitzenberger et al., 2001). However, they draw on rightcensored IABS data that allow for very limited inferences on the returns to education in the upper quantiles. In the lower half of the wage distribution the percentile differences apparently changed little and did not greatly differ from the mean of the distribution.

The observed negative relationship between the wage distribution and the returns to education for two of the three educational groups and the whole sample indicates that employees at the upper part of the distribution have lower returns to education than employees at the bottom. Wage inequality within educational groups would decrease with higher educational attainment because the spread of wages diminishes for higher educational levels and was even observed to decrease over time. According to Pereira and Martins (2000), this is a necessary condition for a negative impact of higher educational attainment on overall wage inequality, which also depends on the part of the distribution where the educational "upgrading" occurs and the magnitude of the returns to education.

These results comply with a recent paper on the heterogeneous returns to education in Germany, which concludes that workers with a more favorable family background earn higher wages and have lower returns to education (Schnabel and Schnabel, 2002). The relatively lower returns to education for the upper part of the wage distribution imply that for these people an additional year of education yields lower net benefits, be it for a lower increase in wages or higher marginal costs of education. According to the model developed by Schnabel and Schnabel (2002), however, the employees with a favorable family background and higher earnings have lower marginal costs of education than the employees with lesseducated parents and lower wages.

The low wage earners seem to benefit more from education than the high wage earners, except for the group of university graduates. An educational expansion might therefore not lead to an increasing wage inequality but rather to a further decrease in Germany. A comparison to other countries shows, that this position is quite unique. Of the fifteen countries analyzed by Pereira and Martins (2000), only Greece and Germany feature a negative relationship while 11 countries feature a positive relationship.

The estimated standard errors of the OLS wage regression performed by Steiner and Wagner (1998) support the presumption of a declining earnings inequality within educational groups between 1984 and 1990 for the GSOEP data but not for the alternative calculations with IABS data. Despite the promising outlook of a negative effect of an educational expansion on wage inequality, a paper investigating the effect of family background and gender on 
returns to education using GSOEP data showed that especially the middle class benefited from a broader access to higher education in West Germany so far (Schnabel and Schnabel, 2002).

\begin{tabular}{|c|c|c|c|c|c|}
\hline \multicolumn{6}{|c|}{ Table 3: Evidence on education - wage inequality link } \\
\hline Authors & Data sets & Sample & Measure & Method & Major Results \\
\hline $\begin{array}{l}\text { Fitzenberger et } \\
\text { al. (2001) }\end{array}$ & IABS & $\begin{array}{l}\text { 1976-1984 } \\
\text { male full-time } \\
\text { employees; } \\
\text { Aged 25-55 }\end{array}$ & $\begin{array}{l}\text { Monthly } \\
\text { earnings }\end{array}$ & $\begin{array}{l}\text { Quantile re- } \\
\text { gressions }\end{array}$ & $\begin{array}{l}\text { Little differences between } \\
\text { lower quantiles and mean; no } \\
\text { change over time }\end{array}$ \\
\hline $\begin{array}{l}\text { Steiner and } \\
\text { Wagner (1998) }\end{array}$ & $\begin{array}{l}\text { GSOEP, } \\
\text { IABS }\end{array}$ & $\begin{array}{l}\text { 1980-90 } \\
\text { male employees; } \\
\text { Aged 16-66 }\end{array}$ & $\begin{array}{l}\text { Monthly } \\
\text { earnings }\end{array}$ & $\begin{array}{l}\text { Earnings equa- } \\
\text { tions (OLS) }\end{array}$ & $\begin{array}{l}\text { Decreasing inequality within } \\
\text { education groups for GSOEP, } \\
\text { not for IABS data }\end{array}$ \\
\hline $\begin{array}{l}\text { Pereira and } \\
\text { Martins }(2000)\end{array}$ & GSOEP & $\begin{array}{l}1984,86,91,95 \\
\text { West Germany }\end{array}$ & $\begin{array}{l}\text { Hourly } \\
\text { wages }\end{array}$ & $\begin{array}{l}\text { Quantile re- } \\
\text { gressions }\end{array}$ & $\begin{array}{l}\text { Negative impact of education } \\
\text { on wage inequality }\end{array}$ \\
\hline $\begin{array}{l}\text { Schnabel and } \\
\text { Schnabel (2002) }\end{array}$ & GSOEP & $\begin{array}{l}1996 \\
\text { full sample and } \\
\text { siblings sample } \\
\text { West Germany; } \\
\text { Aged 17-56 }\end{array}$ & $\begin{array}{l}\text { Hourly } \\
\text { wages }\end{array}$ & $\begin{array}{l}\text { Mincer (OLS), } \\
\text { fixed-effects, } \\
\text { correlated ran- } \\
\text { dom-effects }\end{array}$ & $\begin{array}{l}\text { Importance of family back- } \\
\text { ground, favorable background } \\
\text { leads to lower returns and } \\
\text { higher wages }\end{array}$ \\
\hline $\begin{array}{l}\text { Lauer and Stei- } \\
\text { ner }(2001)\end{array}$ & GSOEP & $\begin{array}{l}\text { 1984-97 } \\
\text { West German } \\
\text { employees; } \\
\text { Aged 30-60 }\end{array}$ & $\begin{array}{l}\text { Hourly } \\
\text { wages }\end{array}$ & $\begin{array}{l}\text { Mincer equa- } \\
\text { tion (OLS) }\end{array}$ & $\begin{array}{l}\text { Overall returns to education } \\
\text { stay remarkably stable; higher } \\
\text { returns for women; returns for } \\
\text { technical college highest, high } \\
\text { school lowest }\end{array}$ \\
\hline Prasad (2000) & GSOEP & $\begin{array}{l}1984-97 \\
\text { full-time workers } \\
\text { West Germany; } \\
\text { Aged 17-65 }\end{array}$ & $\begin{array}{l}\text { Hourly } \\
\text { wages }\end{array}$ & $\begin{array}{l}\text { Quantile re- } \\
\text { gressions }\end{array}$ & $\begin{array}{l}\text { Positive impact of education } \\
\text { on wage inequality for univ. } \\
\text { degree, negative for other } \\
\text { workers }\end{array}$ \\
\hline
\end{tabular}

\subsection{Changes in the Distribution of Education and its Effects on the Wage Distribution}

As mentioned above when discussing the linkage between education and wage inequality, another aspect is the analysis of changes in the distribution of education and its effect on the wage distribution. Changes in the distribution of education in Germany have been described in section 3 of this literature review. Now, the focus is on how these changes affected the distribution of wages.

\section{The Data Sources}

In order to conduct a cross-national study, Devroye and Freeman (2001) use crosscountry information on test scores as reported by the OECD's International Adult Literacy Survey (IALS) and earnings information reported by the OECD Employment Outlook. The IALS has been conducted by asking the same questions (in the official language of each country) to adults in twelve countries. Major fields the questions referred to are document 
literacy, prose literacy and quantitative literacy. The countries considered in this study are Belgium, Canada, Germany, Great Britain, Ireland, the Netherlands, New Zealand, North Ireland, Sweden, Switzerland, and the U.S., where a major focus is given to a comparison between the U.S., Germany, the Netherlands and Sweden. In addition to the IALS data, similar information on the U.S. from the 1992 National Adult Literacy Survey (NALS) is used.

In a further cross-country analysis, Bedard and Ferrall (1997) use data on eleven countries (including West Germany), where information on test score dispersion comes from the First (1962) and Second (1982) International Mathematics Examinations (IME) and data documenting the cohort's wages later in life comes from the Luxembourg Income Study (LIS) and national panel studies they do not specify in detail. The IME data includes information on the following countries: Australia, Belgium, Finland, France, West Germany, Japan, the Netherlands, Sweden, Ontario, the U.K., and the U.S.A.

As described above, Dustmann (2001) uses West German data from the GSOEP waves 1984-1987. Only individuals at least 21 and less than 66 years of age are considered. Additionally, in order to compare the educational and the wage distribution, for this part of the analysis IABS data (compare section 2) are used.

\section{Methods}

Devroye and Freeman (2001) conduct an analysis on an aggregated level. Their study examines coefficients of variation in IALS test scores in order to illustrate inequality in skills. Also, test scores are considered by within-country score quintiles and earning quintiles separately. Later on, a two-stage regression analysis is conducted in order to assess the influence of the distribution of skills on the cross-country distribution of earnings: In a first stage log earnings are regressed on skills (test scores) and other explanatory variables (gender, immigrant status, age and age squared) for each country. Secondly, the coefficients on skill and the residual variances are examined in order to find out what one country's distribution would look like given another country's skill distribution. Additionally, Devroye and Freeman (2001) examine standard deviations of log earnings separately by skill bands in the middle part of the test score distribution. Another way of analyzing the cross-country differences is to compare the dispersion of earnings by narrow test score categories across countries. Finally, Devroye and Freeman (2001) estimate a linear regression model: Log earnings are regressed on categorical variables indicating an individual's position in the distribution of test scores where score intervals of different sizes are considered. 
Bedard and Ferrall (1997) examine Gini coefficients as summary measures of wage and test score dispersions, where test scores of thirteen year olds in 1962 and 1982 and the same cohort's wages later in life are analyzed. In addition they draw Lorenz curves on these distributions.

Beside the examination of educational attainment as described in section 3, on a micro level, Dustmann (2001) links the distribution of wages and of education through parental influences. The modeling of the influence of parental background has been described above (section 3). In order to find out how parental characteristics influence (log) wages the following regression approach is used: Wages are regressed on the secondary school degree conditional on parental characteristics. The probability to hold a special secondary school degree conditional on the background characteristics is obtained from the results of the ordered probit-model (see above).

\section{Major Results Referring to Germany}

On an aggregated level, Devroye and Freeman (2001) consider the fact that both the earnings and educational inequalities differ among developed countries and ask the question whether differences in the distribution of earnings can partly be explained by differences in the distribution of skills. They decompose the difference in the standard deviation of earnings between countries and conclude that skill inequality determines not more than 7 percent of the cross-national difference in earnings inequality. Overall, they conclude that the cross-country differences in the dispersion of skills, as measured in test scores or alternatively in years of schooling, hardly explain the difference in the dispersion of pay. Below, some of the results referring to Germany are summarized. In a descriptive cross-country consideration, Devroye and Freeman (2001) illustrate that the coefficient of variation in skills (measured by IALS test scores) is positively correlated with the 90-10 earnings ratio. Both the measure for skills and for earnings differentials, are relatively low in Germany: The coefficient of variation in skills is lowest in Germany and only two countries (Belgium and Sweden) have lower 90-10 earnings differentials than Germany. Interestingly, in Germany, the test scores in the lowest quintile of the earnings distribution are hardly lower compared to the scores at the highest quintile (294 and 308 respectively). Furthermore, the scores in the lowest quintile are higher than the scores in the middle quintiles. When looking at the standard deviations of log earnings separately by skill bands in the middle part of the test score distribution, one finds that the dispersion in the EU countries (including Germany) is lower than in the U.S. Additionally, the dispersion of earnings is lower in the EU countries at each quintile of the pay distribution (except 
from the highest quintile for Germany) than in the U.S. Finally, regressing log earnings on categorical variables indicating an individual's position in the distribution of test scores, Devroye and Freeman (2001) find that in Germany, as well as in the other examined EU countries, the dispersion of earnings hardly decreases as narrower score intervals are used. This is astounding since one would expect that the mean standard error of log earnings decreases and approaches some fixed value as narrower score intervals are chosen (as it is the case for the U.S.). Additionally, at any level of test score dispersion or number of score groups, the dispersion of log earnings is much lower in Germany compared to the U.S.

As a major result, Bedard and Ferrall (1997) find that the wage dispersion is generally lower than the test score dispersion across countries as well as over time. There is a negative correlation between wage and skill dispersion. One possible interpretation given in this paper is that increases in the wage dispersion may be caused by union power, governmental wage policy and skill biased technological change, while younger workers bring more and more equal skills to the labor market. Within the scope of this literature review, we will summarize more detailed results, where we put an emphasis to the findings referring to (West) Germany. Comparing Gini coefficients for the IME countries, one finds that both test score as well as the dispersion of wages later in life are comparably low in West Germany for the considered 1962 cohort (no information on the 1982 cohort seems to be available). Only Finland (Gini coefficient of 0.104) and Belgium (0.131) have less score dispersion than West Germany (0.133), and the Gini coefficient is highest in the U.K. (0.211). Concerning wage inequality, only wages in Japan seem to be more equal (0.061) than West German wages (0.093), while the highest Gini coefficient refers to the U.S. (0.143). Looking at the Gini coefficients for the different countries, Bedard and Ferrall (1997) find a negative correlation for the Gini coefficients on test scores and the median scores. Furthermore, the Gini coefficient in wages is smaller than the coefficient on the test scores in most countries (including West Germany). Similarly, looking at Lorenz curves, the score curve is below the wage curve for nearly all observations.

Dustmann (2001) finds that even if there is a small convergence in secondary education (i.e. lower educational inequality), there is little convergence in the earnings individuals attain later in live. A possible link between both the distribution of wages and of education works through parental background. The parents' social class especially influences their children's secondary school choice which is made at an early time in the children's life (at the age of ten) in Germany. This influence yields to wage differentials later in the children's life. 
Dustmann (2001) concludes that observed cross-country differences in education and wage outcomes might be caused by differences in educational institutions.

Finally, the study by Bender and Dietrich (2001) mentioned in section 3 of this literature review looks at the proportions of individuals which are full-time employed or unemployed as measures of labor market success. The study concludes that the better educated 1971 cohort is more successful in the labor market than the 1964 cohort. However, Bender and Dietrich (2001) do not explicitly link education and labor market outcome. The better placement in the labor market could also be caused by different economical and demographic conditions of the 1971 birth cohort.

\section{Conclusions}

Summarizing the existing literature leads to the conclusion that there is a relative stability in wage inequality, both between and within educational levels, and in the returns to education. Most change occurred in East Germany, with a widening of the wage distribution. The lower returns to education for the upper quantiles of the wage distribution compared to the lower part suggest that an increase in the general level of educational attainment benefits the low wage earners relatively more.

The inequality in education has decreased, especially concerning educational participation of children from disadvantaged social backgrounds. In the same time, the average educational attainment has risen, with a fall in the percentage of low educated and a rising proportion of the high educated. The observations of a stable wage inequality and the rising average educational level comply with the results on the link between education and wage inequality. Returns to education are found to be slightly decreasing along the conditional wage distribution, which allows for a negative effect of an educational expansion on wage inequality. As no drastic changes occurred in the distributions of education and wages over the last decade, the importance of the separate factors is difficult to illustrate, however.

Scope for further research includes an analysis of the link between education and wage inequality for different cohorts and for the most recent data. Moreover, the evidence on the direct link between the distribution of wages and the distribution of education is scarce in Germany. Especially studies relating the distribution and development of cognitive skills instead of formal schooling to wages hardly exist. 


\section{References}

Abraham, K. and S. Houseman (1995), Earnings Inequality in Germany, in: Freeman, R. and L. Katz (Eds), Differences and Changes in Wage Structures, University of Chicago Press, 371-403.

Atkinson, A. (1995), The Economics of Inequality, Oxford, Clarendon Press.

Becker, G. (1964), Human Capital: A Theoretical and Empirical Analysis with Special Reference to Education, New York, Columbia University Press.

Bedard, K. and C. Ferrall (1997), Wage and Test Score Dispersion: Some International Evidence, Luxembourg Income Study Working Paper No. 156.

Below, S. von (1999), Bildungschancen von Jugendlichen in Ost- und Westdeutschland, in: Luettinger, P. (Ed.), Sozialstrukturanalysen mit dem Mikrozensus, Mannheim.

Bender, S. and H. Dietrich (2001), Unterschiedliche Startbedingungen haben langfristige Folgen. Der Einmündungsverlauf der Geburtskohorten 1964 und 1971 in Ausbildung und Beschäftigung - Befunde aus einem IAB-Projekt, IAB Werkstattbericht 11, Institut für Arbeitsmarkt- und Berufsforschung, Nürnberg.

Blau, F. and L. Kahn (1996), International Differences in Male Wage Inequality: Institutions versus Market Forces, Journal of Political Economy 104, 791-837.

Blau, P. and O. Duncan (1967), The American Occupational Structure, New York.

Blinder, A. (1973), Wage Discrimination: Reduced Form and Structural Estimates, Journal of Human Resources $8,436-55$

Blossfeld, H. (1993), Höherqualifizierung und Verdrängung - Konsequenzen der Bildungsexpansion in den Siebziger Jahren, in: Müller, W. and M. Haller (Eds), Beschäftigungssystem im gesellschaftlichen Wandel, Frankfurt am Main, Campus, 184-240.

Boudon, R. (1974), Education, Opportunity, and Social Inequality. Changing Prospects in Western Society, New York, Wiley.

Bushinsky, M. (1994), Changes in the US Wage Structure 1963-1987: Application of Quantile Regression, Econometrica 62 (2), 405-58.

Devroye, D. and R. Freeman, (2001), Does Inequality in Skills Explain Inequality of Earnings Across Advanced Countries?, NBER Working Paper No. 8140, Cambridge.

Dustmann, C. (2001), Parental Background. Primary to Secondary School Transitions and Wages, IZA Discussion Paper No. 367, Bonn.

Fitzenberger, B. (1999), Wages and Employment Across Skill Groups - An Analysis for West Germany, PhysicaVerlag.

Fitzenberger, B. and G. Wunderlich (2000), Gender Wage Differences in West Germany: A Cohort Analysis, ZEW Discussion Paper No. 00-48, Mannheim.

Fitzenberger, B., R. Hujer, T. MaCurdy and R. Schnabel (2001), Testing for Uniform Wage Trends in WestGermany: A Cohort Analysis Using Quantile Regressions for Censored Data, Empirical Economics 26, 41-86.

Franz, W. and V. Steiner (2000), Wages in the East German Transition Process: Facts and Explanations, German Economic Review 1 (3), 241-269.

Freeman, R. and L. Katz (1992), Rising Wage Inequality: The United States vs. Other Advanced Countries, in: Freeman, R. (Ed.), Working Under Different Rules, New York, Russell Sage Foundation, 29-62. 
Gang, I. and M. Yun (2002), Decomposing Male Inequality Change in East Germany During Transition, IZA Discussion Paper No. 579, Bonn.

Gang, I. and M. Yun (2001), The Gender Wage Gap and Discrimination, East Germany 1990-1997, Vierteljahrshefte zur Wirtschaftsforschung 70 (1), 123-27.

Gang, I. and K. Zimmermann (1999), Is Child Like Parent? Educational Attainment and Ethnic Origin, IZA Discussion Paper No. 57, Bonn.

Gottschalk, P. and T. Smeeding (1997), Cross-national Comparisons of Earnings and Income Inequality, Journal of Economic Literature 35 (2), 633-87.

Handl, J. (1984), Chancengleichheit und Segregation: Ein Vorschlag zur Messung ungleicher Chancenstrukturen und ihrer zeitlichen Entwicklung, Zeitschrift für Soziologie 13, 328-245.

Handl, J. (1985), Mehr Chancengleichheit im Bildungssystem. Erfolg der Bildungsreform oder statistisches Artefakt?, KZfSS 37 (4), 698-722.

Henz, U. and U. Maas (1995), Chancengleichheit durch die Bildungsexpansion?, KZfSS 47 (4), 605-33.

Hunt, J. (1999), Post-Unification Wage Growth in East Germany, NBER Working Paper No. 6878, Cambridge.

Hunt, J. (2002), The Transition in East Germany - When Is a Ten Percent Fall in the Gender Wage Gap Bad News?, Journal of Labor Economics 20 (1), 148-69.

Köhler, H. (1992), Bildungsbeteiligung und Sozialstruktur in der Bundesrepublik. Zu Stabilität und Wandel der Ungleichheit von Bildungschancen, Berlin.

Lauer, C. (2000), Gender Wage Gap in West Germany: How Far Do Gender Differences in Human Capital Matter?, ZEW Discussion Paper No. 00-07, Mannheim.

Lauer, C. (2002a), A Model of Educational Attainment. Application to the German Case, ZEW Discussion Paper No. 02-06, Mannheim.

Lauer, C. (2002b), Enrolments in Higher Education in West Germany: Do Economic Incentives Matter? Education and Training 44 (4/5), 179-185.

Lauer, C. (2003a), Education and Labour Market Outcomes: A French-German Comparison, ZEW, mimeo, Mannheim.

Lauer, C. (2003b), Familiy Background, Cohort and Education. A French-German Comparison based on a multivariate ordered probit model of educational attainment, Labour Economics, 10 (2), 231-251.

Lauer, C. and V. Steiner (2001), Education and Earnings in Europe - Germany, in: Harmon, C., I. Walker and N. Westergaard-Nielsen (Eds), Education and Earnings in Europe, A Cross Country Analysis of the Returns to Education, Cheltenham.

Maier, G. and P. Weiss (1990), Modelle diskreter Entscheidungen. Theorie und Anwendung in den Sozial- und Wirtschaftswissenschaften, Wien, Springer.

Mare, R. (1981), Change and Stability in Educational Stratification, American Sociological Review 46, $72-87$.

Mincer, J. (1974), Schooling, Experience and Earnings, New York, Columbia University Press.

Möller, J. (1996), Technological Change, Unemployment, and Recent Trends in Human Capital Formation - Did the German Wage Structure Respond to these Impulses?, Regensburger Diskussionsbeiträge Vol. 280, University of Regensburg.

Möller, J. and L. Bellmann (1996), Qualifikations- und industriespezifische Lohnunterschiede in der Bundesrepublik Deutschland, ifo Studien 421, 235-72. 
Müller, W. (1994), Bildungsungleichheit im sozialen Wandel, KZfSS 46 (1), 1-42.

Müller, W. and D. Haun (1994), Bildungsexpansion und Bildungsungleichheit, in: Glatzer, W. (Ed.), Einstellungen und Lebensbedingungen in Europa, Frankfurt am Main, Campus, 225-68.

Oaxaca, R. (1973), Male-Female Wage Differentials in Urban Labor Markets, International Economic Review 14 (3), 693-709.

Odink, J. and J. Smits (2001), The Inequality of the Wage Distribution in 15 European Countries, in: Asplund, R. (Ed.), Public and Private Returns to Education - PURE Final Report.

Peisert, H. (1967), Soziale Lage und Bildungschancen in Deutschland, München, Piper.

Pereira, P. and P. Martins (2000), Does Education Reduce Wage Inequality? Quantile Regressions Evidence from Fifteen European Countries, mimeo, Universidade Nova de Lisboa.

Prasad, E. (2000), The Unbearable Stability of the German Wage Structure: Evidence and Interpretation, IMF Working Paper No. 00/22, Washington D.C.

Ram, R. (1990), Educational Expansion and Schooling Inequality: International Evidence and Some Implications, The Review of Economics and Statistics 72 (2), 266-74.

Riphan, R. (2002), Bruttoeinkommensverteilung in Deutschland 1984-1999 und Ungleichheit unter ausländischen Erwerbstätigen, DIW Diskussionspapiere No. 272.

Schimpl-Neimanns, B. (2000), Hat die Bildungsexpansion zum Abbau der sozialen Ungleichheit in der Bildungsbeteiligung geführt? Methodische Überlegungen zum Analyseverfahren und Ergebnisse multinomialer Logit-Modelle für den Zeitraum 1950-1989, ZUMA Arbeitsbericht, 02, Mannheim.

Schnabel, I. and R. Schnabel (2002), Family and Gender Still Matter: The Heterogeneity of Returns to Education in Germany, ZEW Discussion Paper No. 02-67, Mannheim.

Steiner, V. and K. Wagner (1998), Has Earnings Inequality in Germany Changed in the 1980s?, Zeitschrift für Wirtschafts- und Sozialwissenschaften 118, 29-59.

Steiner, V. and T. Hölzle (2000), The Development of Wages in Germany in the 1990s - Descriptions and Explanations, in: Hauser, R. and I. Becker (Eds), The Personal Distribution of Income in an International Perspective, Springer, 7-30. 


\section{Appendix}

\section{A brief review on the measurement of inequality}

As becomes clear from this literature review, there are various measurements of inequality. Results can vary depending on what kind of measurement is used and therefore it is important to know about the measurement methodologies and their (normative) implications. This is why this section briefly reviews some prominent measurements of inequality.

\section{Wage Percentile Ratios}

One measurement which is often used in the empirical literature is the ratio of wage percentiles. This ratio compares the wage of the $x$ percent highest wage earners with the wage of the $x$ percent highest wage earners. The 90/50-percentile ratio for example compares the wage of the 90 percent highest wage earners with the wage of the 50percent highest wage earners. A higher ratio therefore is an indicator for higher wage inequality.

\section{Inequality Indices}

Alternatively, a large number of inequality indices is used. One prominent example of an inequality index is the variance. The formula for the variance is given by:

$$
\sigma^{2}=\frac{1}{n} \sum_{\mathrm{i}=1}^{\mathrm{n}}\left(\mathrm{y}_{\mathrm{i}}-\mu\right)^{2}
$$

Here, $y_{i}$ is an individual's wage, $\mu$ is the mean wage and $n$ is the population size. Thus, the variance is the sum of the squared deviations of the individuals' wages from the mean wage, divided by the population size. One normative aspect of the variance is that it implies increasing inequality aversion, i.e. larger deviations are weighted more than smaller deviations from the mean. A further point is the mean dependency of the variance. In order to avoid mean dependency one can use the squared variation coefficient:

$$
\mathrm{V}^{2}=\frac{\sigma^{2}}{\mu^{2}} .
$$


Many empirical studies use the Gini coefficient in order to measure inequality. The Gini coefficient refers to the Lorenz curve, which indicates how many percent of the households earn how many percent of the total income that households earn. If wages were distributed equally, $x$ percent of the households would earn $x$ percent of the total wage income. Figure 1 shows an example of a Lorenz curve together with the line of equal wage distribution:

percent of the

total wage income

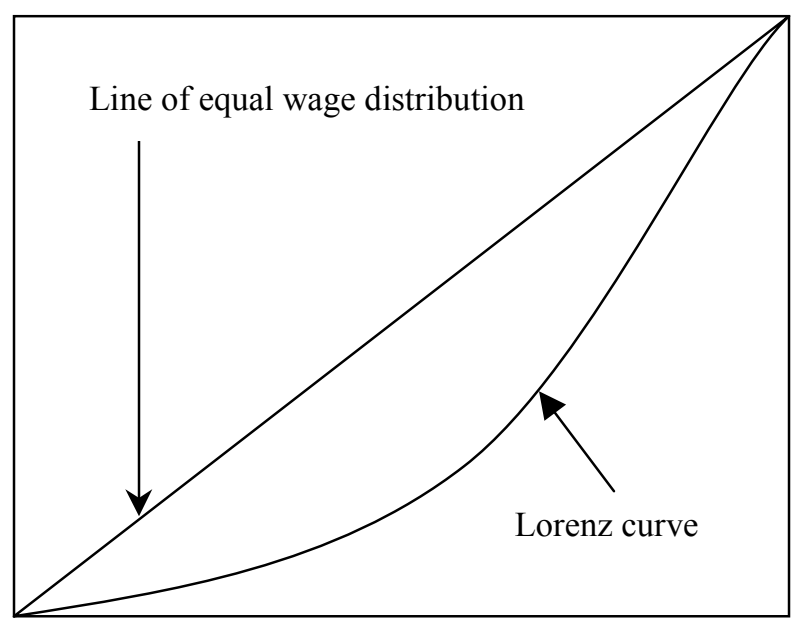

$(100 \% / 100 \%)$

percent of households

The more the Lorenz curve deviates from the line of equality, the higher the wage inequality. The Gini coefficient is defined as the area between the Lorenz curve and the line of equal wages, divided by the area below the line of equal wages, i.e. the higher the Gini coefficient the higher the wage inequality. It is intuitively clear that, if we compare two wage distributions, a wage distribution coming along with a higher Gini coefficient is more unequal. However, if the Lorenz curves intersect and two different Lorenz curves result in the same Gini coefficient, the judgement on inequality is not that simple. Using the Gini coefficient implies a normative judgement since alternative inequality indices can put more or less weight on the top or the bottom of the wage distribution and therefore come up with different implications on inequality.

While the Gini coefficient is very prominent, the Theil index is less often used in studies on wage inequality in Germany. The Theil index is defined as:

$$
\mathrm{T}=\frac{1}{\mathrm{n}} \sum_{\mathrm{i}=1}^{\mathrm{n}} \frac{\mathrm{y}_{\mathrm{i}}}{\mu} \log \left(\frac{\mathrm{y}_{\mathrm{i}}}{\mu}\right)
$$


The Theil index is normally used because of its advantage of additive separability. The contributions of different groups can easily be separated. This becomes clear if we look at the following formulation of the Theil index:

$$
\mathrm{T}=\sum_{\mathrm{i}=1}^{\mathrm{n}} \frac{\mathrm{y}_{\mathrm{i}}}{\mathrm{Y}} \log \left[\left(\frac{\mathrm{y}_{\mathrm{i}}}{\mathrm{Y}} / \frac{1}{\mathrm{n}}\right) \text { with } Y=\sum_{p=1}^{n} y_{i}\right.
$$

If a group's share on the overall population corresponds to its share on the overall wage income, the group's contribution to inequality equals zero (because $\left(\mathrm{Y}_{\mathrm{i}} / \mathrm{Y}\right) /(1 / \mathrm{n})$ equals 1$)$.

\section{Decomposition techniques}

The measurements above analyze wage inequality by looking at the wage distribution. An alternative way is to compare the wage inequality of two groups by taking the mean wages and decomposing the means. According to the decomposition technique introduced by Blinder (1973) and Oaxaca (1973) observed inequality in mean wages is decomposed into differences in observed characteristics (e.g. differences in human capital like education) and differences in the returns to observed characteristics and residual effects. 